\title{
ESTUDO FITOQUÍMICO E BIOLÓGICO DAS CASCAS DE Erythrina velutina Willd. - FABACEAE (LEGUMINOSAE - PAPILIONOIDEAE)
}

\section{PHITOCHEMICAL AND BIOLOGICAL STUDY FROM ERYTHRINA VELUTINA WILLD., FABACEAE (LEGUMINASAE- PAPILIONOIDEAE) BARK.}

\author{
Virtuoso, $\mathrm{S}^{1}$; Miguel, $\mathrm{Og}^{2}$. \\ RECEBIDO:MARÇO/2005 ACEITO: ABRIL/2005
}

Autora da dissertação, aluna do programa da Pós-graduação em Ciências Farmacêuticas em nível de mestrado da UFPR ${ }^{1}$; Orientador da dissertação². e-mail: obdulio@ufpr.br

Data de defesa: 24/02/2005

\section{RESUMO}

A Erythrina velutina Willd. é conhecida popularmente como "mulungu", suas cascas são utilizadas principalmente pela população do nordeste brasileiro devido a suas propriedades calmante, sudorífica, emoliente e anestésica local. A pesquisa teve como propósitos o isolamento de substâncias químicas, a partir de técnicas cromatográficas, presentes no extrato bruto e frações deste (hexano, diclorometano, acetato de etila e hidroalcoólica remanescente). A identificação dos compostos isolados foi realizada por meio da análise dos dados das espectroscopias de ultravioleta, infravermelho e ressonância magnética nuclear de carbono e hidrogênio; a verificação da atividade antibacteriana do extrato bruto foi realizada através dos testes de difusão em disco e concentração inibitória mínima e, da fração hexano por teste de difusão em disco, além disso também foi procedida a verificação da atividade alelopática na germinação e alteração do crescimento da radícula e hipocótilo das sementes de Lactuca sativa para diferentes concentrações do extrato bruto e frações, os dados foram analisados estatisticamente pela análise de variância e teste de comparação múltipla de médias de Scott \& Knott. Na fração hexano foram identificados o ácido fênico, ácido cinâmico, aamirina, estigmasterol, b-amirina, b-sitosterol e lupeol por cromatografia gasosa e isolados o estigmasterol em mistura com o b-sitosterol. Da fração diclorometano foram isolados dois alcalóides e as estruturas propostas são eritralina, que foi identificada por comparação de seus dados espectrais com os dados publicados e já foi isolada desta espécie, 8-oxo-11b-metoxieritralina e eritrinina (não relatadas para a espécie); da fração hidroalcoólica remanescente isolou-se um composto que exibe algumas características de açúcar monocíclico, ainda não completamente identificado. O extrato bruto e a fração hexano demonstraram atividade antibacteriana moderada, em relação aos antibióticos controle, contra o Staphylococcus aureus e Streptococcus pyogenes. A germinação das sementes de Lactuca sativa não foi inibida e o crescimento da radícula e hipocótilo destas plântulas para o extrato bruto e frações foi estatisticamente significativo e diferente dos controles com água e etanol, a fração hidroalcoólica remanescente teve a maior atividade e alterou a morfologia das plântulas causando enovelamento, ausência de pêlos radiculares e ausência de folíolos. Cabe salientar que a atividade antibacteriana, a atividade alelopática e a presença de estigmasterol e o composto isolado da fração hidroalcoólica remanescente ainda não haviam sido citadas na literatura conforme levantamento bibliográfico para Erythrina velutina.

Palavras-chave: alelopatia, análise estatística, atividade antibacteriana, microbiologia, alcalóides, estigmasterol. 


\begin{abstract}
Erythrina velutina Willd. is popularly known as mulungu, and its bark is used especially by the population of the Brazilian northeast owning to its sedative, sudorific, emollient and topic anaesthetic properties. This research is aimed at isolating the chemical substances in the crude extract and its partitions (hexane, dichloromethane, ethyl acetate and hydro alcoholic remaining fractions), through chromatographic techniques. The analysis of the spectrum copies of ultraviolet, infrared and nuclear magnetic resonance of carbon and hydrogen were used in the identification of the isolated compounds. The antibacterial activity of the crude extract was verified by using disk diffusion method and minimal inhibition concentration (MIC), and hexane fraction activity was verified through the disk diffusion method, and besides that the allelopathic activity in the germination and growth of the radicle and plantule of the Lactuca sativa seeds was checked at different concentrations of crude extract and fractions. Data were statistically examined by analysis of variance (ANOVA) and Scott Knott multiple comparison test. The hexane fraction GC showed fenic acid, cinnamic acid, a-amirin, stigmasterol, b-amirin, bsitosterol and lupeol by gas chromatography; stigmasterol was isolated and identified as the major compound in the mixture with b-sitosterol. Two alkaloids were isolated from the dichloromethane fraction and the structures found were: erythraline that has been identified by comparing its spectral characteristics to its published ones and has been isolated from this gender, and 8oxo11(-methoxyerythraline and erythrinin which had not been related to this gender before; from the remaining hidroalcoholic fraction it was possible to segregate a compound that seems to have monocyclic sugar characteristics, but has not been thoroughly identified so far. The crude extract and the hexane fraction gave evidence of moderate antibacterial activity in relation to the antibiotics control, against Staphylococcus aureus and Streptococcus pyogenes. The germination of Lactuca sativa seeds was not inhibited and the growth of the radicle and hypocotyls to the amount of crude extract and fractions were statistically significant and different from the water and ethanol control. The remaining hidroalcoholic fraction was the most active and that caused the plantules morphology to show alterations such as curling, radicle hair absence and follicle absence. It seems important to emphasize that antibacterial activity, allelopathic activity, stigmasterol presence and the isolated compound from the remaining hidroalcoholic fraction had never been mentioned before in literature according to a bibliographic survey of Erythrina velutina.
\end{abstract}

Key-words: allelopathy, statistical analysis, antibacterial activity, microbiology, alkaloids, stigmasterol. 